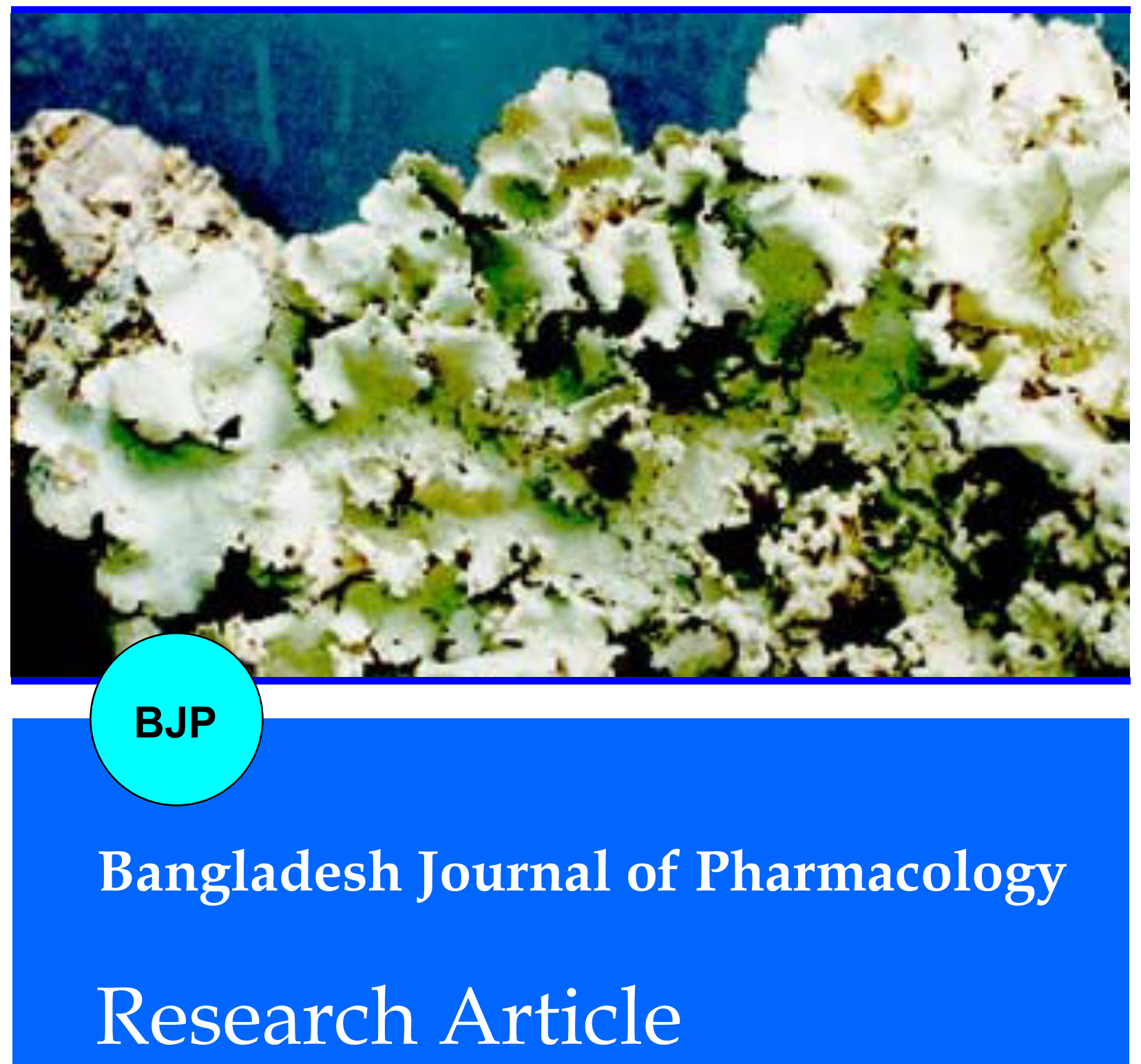

Antihyperglycemic and anti-oxidant activity of various fraction of Parmotrema hababianum in streptozotocin-induced diabetic rat 
Abstracted/indexed in Academic Search Complete, Asia Journals Online, Bangladesh Journals Online, Biological Abstracts, BIOSIS Previews, CAB Abstracts, Current Abstracts, Directory of Open Access Journals, EMBASE/Excerpta Medica, Google Scholar, HINARI (WHO), International Pharmaceutical Abstracts, Open J-gate, Science Citation Index Expanded, SCOPUS and Social Sciences Citation Index;

ISSN: $1991-0088$

\title{
Antihyperglycemic and anti-oxidant activity of various fraction of Parmotrema hababianum in streptozotocin-induced diabetic rat
}

\author{
Ayyappadasan Ganesan, Amutha Mahesh, Jeya Prakash Sundararaj, Kalaiselvi Mani and \\ Ponmurugan Ponnusamy
}

Department of Biotechnology, K. S. Rangasamy College of Technology, Tiruchengode 637 215, Tamil Nadu, India.

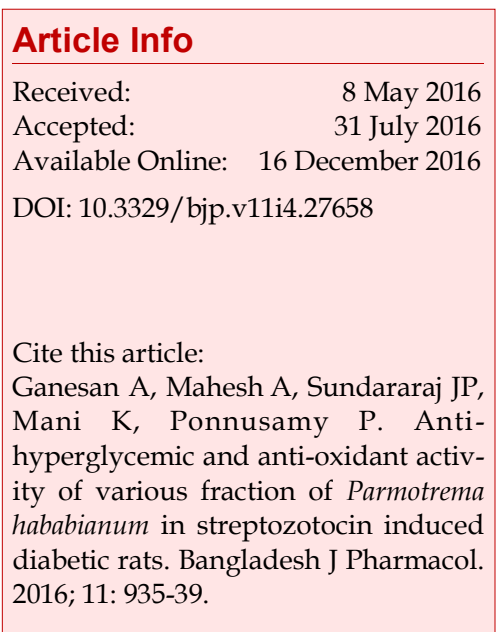

\begin{abstract}
The core objective of this study was to investigate the in vitro anti-oxidant and antihyperglycemic effect of the ethanol extract of Parmotrema hababianum in streptozocin-induced diabetic rats for 42 days. The extract showed nearly all anti-oxidant activities with maximum presence. The treatment with extract in diabetic rats at the dosage level of 100 and $200 \mathrm{mg} / \mathrm{kg}$, which is compared with diabetic control and glibenclamide at a dosage level of $4 \mathrm{mg} / \mathrm{kg}$ and the biochemical parameters such as blood glucose, total cholesterol, triglycerides, HDL, LDL, insulin, total protein, urea and creatinine were assessed. The extract showed positive correlation $(p<0.001)$ in reducing blood glucose level as compared to the control. Moreover, there was a significant $(p<0.01)$ decrease in TC, TG, LDL, SGPT, SGOT, urea and creatinine level and significant $(\mathrm{p}<0.01)$ increase in HDL and insulin level. Thus, the results of this study show considerable efficacy in curing diabetes with potent anti-oxidant and antihyperglycemic activity.
\end{abstract}

\section{Introduction}

Diabetes mellitus is considered as a greater health concern all over the world. Expected result shows that in 2030, 6 out of 10 countries in Asia will having higher number of diabetic patients ( $\mathrm{Ku}$ and Kegels, 2013). Free radicals are reactive oxygen species (ROS) that are integrated into the physiology of the human system (Shih et al., 2006). An excess production of these ROS leads to oxidative stress to the normal cellular functions. Anti-oxidant molecule protects the cellular components from the oxidation effect of free radicals (Jeya et al., 2015). Thus, they are important in protecting against diseases, such as arthritis, diabetes mellitus, carcinogenesis and cardiovascular diseases, developed in response to oxidative stress (Sangameswaran et al., 2009).

Searching of new drug molecule different from natural resources is gaining importance to mankind. The un- explored and unexploited plant species having a resource of therapeutic potential is a symbiont, lichen. Lichens are composite organisms consisting of fungi and other species either algae or cyanobacteria. Lichen metabolites spur diverse biological activities, such as antimicrobial, antitumor, antimutagenic, antiherbivore, and allergenic (Atalay et al., 2011). The biological activity of an extract can be determined by the presence of phenolic compounds, such as flavonoids, phenolic acids and total phenols (Brown and Rice, 1998). Lichens are also known for having higher phenolic content, which has various applications.

This study will enable researchers to understand various pharmaceutically active compounds in various lichen sample extracts (Muller, 2001). It discusses about the antidiabetic, anti-oxidant potential as well as phenolic content in various extracts obtained from lichen Parmotrema hababianum. 


\section{Materials and Methods \\ Plant source and preparation of lichen extracts}

Lichen sample was collected from the Shevaroy hills region of the Eastern Ghats of Tamil Nadu. The sample was identified by following standard procedures with respect to studying their morphology, anatomy, and chemistry. Thin-layer chromatography was conducted following the procedure established by Walker and James (1980), using solvent system A to identify secondary metabolites. Voucher specimens were deposited in the lichen herbarium of the K. S. Rangasamy College of Technology, Tiruchengode, for reference purposes. Approximately $8 \mathrm{~g}$ samples of each species were powdered and used for the extraction with different solvent systems with increasing polarity (petroleum ether, ethyl acetate, acetone, ethanol, and water) using Soxhlet extractor (Soxhlet, 1879). Using a vacuum desiccator, we subjected the extracts to evaporation in order to form a dry powder. Powdered extracts were stored at $-80^{\circ} \mathrm{C}$ in a deep freezer for further study.

\section{Anti-oxidant activity of lichen extracts}

2,2-Diphenyl-1-picrylhydrazyl (DPPH) free radical capturing assay

Hydrogen free radical quenching assay was performed with different concentrations of lichen extracts $(20,50$, $100,200,400,800$ and $1,000 \mu \mathrm{g} / \mathrm{mL}$ ) in corresponding solvents $(\mathrm{w} / \mathrm{v})$. Ascorbic acid was used as the standard (Khalaf et al., 2008). DPPH solution ( $2 \mathrm{~mL}, 0.002 \%$ ) was mixed with $2 \mathrm{~mL}$ lichen extracts. The reaction mixtures were kept in the dark conditions for $30 \mathrm{~min}$ at $37^{\circ} \mathrm{C}$. The reduction in color intensity was measured at $517 \mathrm{~nm}$ using a UV-visible spectrophotometer (U-2900, Hitachi, Japan).

Ferric reducing power assay (FRAP)

FRAP assay was performed on 20, 50, 100, 200, 400, 800 and $1,000 \mu \mathrm{g} / \mathrm{mL}$ samples of lichen extracts, with ascorbic acid as the standard. Phosphate buffer $(2.5 \mathrm{~mL}$; $200 \mathrm{mM}, \mathrm{pH}$ 6.6) and $1 \%$ potassium ferricyanide solution $(2.5 \mathrm{~mL})$ were added to each concentration. The amount of $\mathrm{Fe}^{2+}$ iron formation was studied by measuring the Perl's prussian blue at $700 \mathrm{~nm}$. The increase in absorbance value indicates the steep reduction in power of lichen extracts (Oyaizu, 1986).

Hydrogen peroxide-reducing activity assay

Hydrogen peroxide activity was assayed by measuring 200, 400, 600, 800 and 1,000 $\mu \mathrm{g} / \mathrm{mL}$ concentrations of lichen extracts. These extracts were added to $0.6 \mathrm{~mL}$ hydrogen peroxide $(40 \mathrm{mM})$. The reaction mix contains hydrogen peroxide and various extracts of lichens were incubated for $10 \mathrm{~min}$ at room temperature and the absorbance was read at $230 \mathrm{~nm}$ against phosphate buffer ( $\mathrm{pH}$ 7.4) as a blank solution. The percentage of inhibition was calculated and then compared with that of ascorbic acid (Ruch et al., 1989).

\section{Total phenolic content of lichen extracts}

The total phenolic content of the lichen extract was analyzed using Folin-Ciocalteu reagent, which was described by Slinkard and Slingleton (1997). Lichen extracts were diluted at a concentration of $1 \mathrm{mg} / \mathrm{mL}$ with respective solvents, from which $0.1 \mathrm{~mL}$ extracts was taken and added to $1 \mathrm{~mL}$ Folin-Ciocalteu reagent (1:1) and $3 \mathrm{~mL} \mathrm{Na}_{2} \mathrm{CO}_{3}(2 \%)$. Color intensity was measured at $760 \mathrm{~nm}$ using gallic acid as a standard.

\section{Animals used}

Adult Wister albino rats weighting 120-150 g of both sex were used in the present study. The experimental animals were fed using standard food pellets with water ad libitum and placed in polypropylene cages for the period of study. The rats were maintained at the temperature range of $23 \pm 2{ }^{\circ} \mathrm{C}$ having the relative humidity of $55-60 \%$ with 12 hours of light and dark cycle.

\section{Diabetes induction at rats}

Diabetes in rats was done using intraperitoneal injection of streptozotocin at the dosage level of $50 \mathrm{mg} /$ $\mathrm{kg}$ (prepared by dissolving in $0.1 \mathrm{M}$ citrate buffer, $\mathrm{pH}$ 4.5 ) by fasting the rats to 16 hours. Induction of diabetes was identified by measuring the fasting blood glucose level (above $250 \mathrm{mg} / \mathrm{dL}$ level was considered as diabetes) after 5 days of induction period. Diabetic rats were orally administered with $5 \%$ glucose solution to avoid the hypoglycemia condition during the streptozotocin administration of diabetes.

\section{Experimental design}

The rats were divided into five groups of six rats each. The ethanolic extracts were administered orally at the doses of 100 and $200 \mathrm{mg} / \mathrm{kg}$ for a period of 42 days by dissolving it in CMC to different groups of diabetic induced rats. Group I (healthy control rats), group II (diabetic control rats), group III (diabetic treated with ethanolic extract of lichen sample $-100 \mathrm{mg} / \mathrm{kg}$ ), group IV (diabetic treated with ethanolic extract of lichen sample $200 \mathrm{mg} / \mathrm{kg}$ ) and group V (diabetic treated with standard drug glibenclamide).

\section{Blood biochemistry}

Finally, the blood was collected from retinal orbital plexuses to all the overnight fasted rats under mild anesthesia. Serum was separated out and blood glucose level was analyzed by Erba diagnostics kit using biochemical analyzer. Lipids profile such as total cholesterol (TC), triglycerides (TG), high density lipoprotein (HDL) and low density lipoprotein (LDL) were analyzed. Blood insulin, urea, protein and 
enzymes like serum glutamic oxaloacetic transaminase (SGOT) and serum glutamic pyruvic transaminase (SGPT) were also studied in various experimental rats.

\section{Results}

The in vitro anti-oxidant effect of different solvent extracts of P. hababianum was shown in the Table I. All the values were calculated in the ascorbic acid equivalent anti-oxidant capacity $\left(\mathrm{AEAC}_{\mathrm{DPPH}}\right)$ of per gram of lichen extracts. The petroleum ether extract of $P$. hababianum showed the maximum activity followed

\begin{tabular}{|c|c|c|c|c|}
\hline \multicolumn{5}{|c|}{ Table I } \\
\hline \multicolumn{5}{|c|}{$\begin{array}{l}\text { Anti-oxidant activity of different extracts of } P . h a b- \\
\text { abianum }\end{array}$} \\
\hline \multirow[t]{2}{*}{ Extracts } & \multicolumn{3}{|c|}{$\mu \mathrm{mol}$ of ascorbic acid/g } & \multirow{2}{*}{$\begin{array}{c}\begin{array}{c}\text { mg gallic acid } \\
\text { equivalent }\end{array} \\
\text { TPC }\end{array}$} \\
\hline & $\begin{array}{l}\text { AEAC } \\
\text { FRAP }\end{array}$ & $\begin{array}{c}\text { AEAC } \\
\text { DPPH }\end{array}$ & $\begin{array}{c}\text { AEAC } \\
\mathrm{H} 2 \mathrm{O} 2\end{array}$ & \\
\hline Methanol & $\begin{array}{l}1446 \\
(4.5)\end{array}$ & *NA & $\begin{array}{l}11.7 \\
(0.3)\end{array}$ & $\begin{array}{r}197.3 \\
(2.7)\end{array}$ \\
\hline Ethanol & $\begin{array}{l}1655 \\
(5.3)\end{array}$ & $\begin{array}{l}98.3 \\
(2.6)\end{array}$ & $\begin{array}{l}25.7 \\
(0.4)\end{array}$ & $\begin{array}{r}224.7 \\
(4.1)\end{array}$ \\
\hline Benzene & $\begin{array}{r}998 \\
(4.1)\end{array}$ & $\begin{array}{l}20.0 \\
(1.1)\end{array}$ & $\begin{array}{r}8.7 \\
(0.1)\end{array}$ & $\begin{array}{l}75.2 \\
(0.7)\end{array}$ \\
\hline Acetone & $\begin{array}{r}620 \\
(3.8)\end{array}$ & NA & NA & $\begin{array}{l}22.5 \\
(1.3)\end{array}$ \\
\hline $\begin{array}{l}\text { Petroleum } \\
\text { ether }\end{array}$ & $\begin{array}{l}1120 \\
(2.7)\end{array}$ & $\begin{array}{r}122.3 \\
(3.4)\end{array}$ & $\begin{array}{l}18.8 \\
(0.2)\end{array}$ & $\begin{array}{r}123.7 \\
(2.7)\end{array}$ \\
\hline Aqueous & $\begin{array}{r}998 \\
(2.9)\end{array}$ & NA & NA & $\begin{array}{l}66.6 \\
(0.9)\end{array}$ \\
\hline
\end{tabular}

All values are expressed as mean \pm SEM $(n=3)$; ${ }^{*}$ A indicates no activity by the activity of ethanol and benzene extracts. Methanol, acetone and aqueous extract did not show any activity towards DPPH. But AEAC FRAP showed activity for all the extracts of $P$. hababianum which was in the progression from ethanol $>$ methanol > petroleum ether $>$ benzene $>$ aqueous $>$ acetone. $\mathrm{AEAC}_{\mathrm{H} 2 \mathrm{O} 2}$ activity of ethanol extract showed maximum activity in P. hababianum with the order followed by activity of petroleum ether, methanol and benzene extracts. But the exception was that acetone and aqueous extracts showed no activity towards

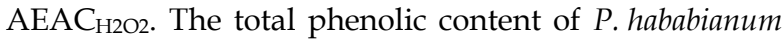
was expressed in terms of gallic acid equivalent that showed the maximum phenolic presence in ethanol extract of about $224.7 \mathrm{mg}$ of gallic acid equivalent.

Blood glucose level of normal (control) and streptozotocin induced diabetic rats were shown in the Table II.

In our study, diabetic rats were treated with ethanolic extracts of two different concentrations because ethanolic extracts of $P$. hababianum showed almost all the maximum activity towards anti-oxidants such as DPPH, FRAP, $\mathrm{H}_{2} \mathrm{O}_{2}$ and total phenolic content. Blood glucose level of diabetic rat was significantly $(\mathrm{p}<0.001)$ higher than the treated group at $0,7,14,21,28,35,42$ days interval. After the successive period of incubation of diabetic rats, there was a significant decrease of blood glucose level in the diabetic treated groups.

During the high concentration of administration of ethanolic extract of $P$. hababianum showed highly significant decrease $(\mathrm{p}<0.001)$ in blood glucose level as measured at $7^{\text {th }}$ day $(211.5 \pm 0.8), 14^{\text {th }}$ day $(202.5 \pm 1.3)$, $21^{\text {th }}$ day $(190.8 \pm 1.0), 28^{\text {th }}$ day $(181.3 \pm 0.9), 35^{\text {th }}$ day $(174.9 \pm 0.8)$ and $42^{\text {th }}$ day $(161.4 \pm 1.4)$. To further know the role of ethanolic extract of $P$. hababianum, there was a significant increase $(\mathrm{p}<0.01)$ of total cholesterol,

Table II

Effect of ethanolic extract of $P$. hababianumon on blood glucose level in streptozotocin-induced diabetic rat

\begin{tabular}{|c|c|c|c|c|c|c|c|}
\hline \multirow[t]{2}{*}{ Groups } & \multicolumn{7}{|c|}{ Blood glucose level (mg/dL) } \\
\hline & 0 day & $7^{\text {th }}$ day & $14^{\text {th }}$ day & $21^{\text {st }}$ day & $28^{\text {th }}$ day & $35^{\text {th }}$ day & $42^{\text {th }}$ day \\
\hline Control & $\begin{array}{l}90.4 \\
(0.4)\end{array}$ & $\begin{array}{l}89.6 \\
(1.1)\end{array}$ & $\begin{array}{l}88.2 \\
(0.9)\end{array}$ & $\begin{array}{l}89.4 \\
(0.8)\end{array}$ & $\begin{array}{l}91.8 \\
(1.3)\end{array}$ & $\begin{array}{l}90.4 \\
(0.6)\end{array}$ & $\begin{array}{l}88.7 \\
(0.7)\end{array}$ \\
\hline Diabetic control & $\begin{array}{r}283.5 \\
(0.5)\end{array}$ & $\begin{array}{r}287.2 \\
(0.5)\end{array}$ & $\begin{array}{r}290.4 \\
(0.8)\end{array}$ & $\begin{array}{r}294.1 \\
(1.07)\end{array}$ & $\begin{array}{r}297.6 \\
(0.9)\end{array}$ & $\begin{array}{r}302.5 \\
(1.2)\end{array}$ & $\begin{array}{r}307.5 \\
(1.1)\end{array}$ \\
\hline Diabetic + Ethanolic extract $(100 \mathrm{mg} / \mathrm{kg})$ & $\begin{array}{r}284.4 \\
(0.9)\end{array}$ & $\begin{array}{r}225.6 \\
(1.4)\end{array}$ & $\begin{array}{r}219.9 \\
(1.7)\end{array}$ & $\begin{array}{r}200.3 \\
(1.0)\end{array}$ & $\begin{array}{r}181.8 \\
(1.2)\end{array}$ & $\begin{array}{r}173.4 \\
(0.5)\end{array}$ & $\begin{array}{r}155.7 \\
(1.3)\end{array}$ \\
\hline Diabetic + Ethanolic extract $(200 \mathrm{mg} / \mathrm{kg})$ & $\begin{array}{r}286.7 \\
(0.7)\end{array}$ & $\begin{array}{r}211.5 \\
(0.8)\end{array}$ & $\begin{array}{r}202.5 \\
(1.3)\end{array}$ & $\begin{array}{l}175.8 \\
(1.03)\end{array}$ & $\begin{array}{r}161.3 \\
(0.9)\end{array}$ & $\begin{array}{r}144.9 \\
(0.8)\end{array}$ & $\begin{array}{r}129.4 \\
(1.4)\end{array}$ \\
\hline Diabetic + Glibenclamide (4 mg/kg) & $\begin{array}{r}305.3 \\
(1.4)\end{array}$ & $\begin{array}{r}256.9 \\
(0.5)\end{array}$ & $\begin{array}{r}204.4 \\
(0.9)\end{array}$ & $\begin{array}{r}171.4 \\
(1.4)\end{array}$ & $\begin{array}{c}145.8 \\
(1.04)\end{array}$ & $\begin{array}{r}119.5 \\
(0.8)\end{array}$ & $\begin{array}{l}91.7 \\
(1.5)\end{array}$ \\
\hline
\end{tabular}

All values are expressed as mean $\pm \operatorname{SEM}(n=6)$ 
Table III

Effect of ethanolic extract of $P$. hababianum on serum profile in streptozotocin- induced diabetic rats for 42

\begin{tabular}{|c|c|c|c|c|c|c|c|c|c|}
\hline Groups & $\begin{array}{l}\text { Insulin } \\
(\mu \mathrm{IU} / \mathrm{L})\end{array}$ & $\begin{array}{c}\text { TC (mg/ } \\
\text { dL) }\end{array}$ & $\begin{array}{c}\text { TG (mg/ } \\
\text { dL) }\end{array}$ & $\begin{array}{c}\text { HDL } \\
(\mathrm{mg} / \mathrm{dL})\end{array}$ & $\begin{array}{c}\text { LDL } \\
(\mathrm{mg} / \mathrm{dL})\end{array}$ & $\begin{array}{l}\text { SGPT } \\
\text { (IU/L) }\end{array}$ & $\begin{array}{l}\text { SGOT } \\
(\mathrm{IU} / \mathrm{L})\end{array}$ & $\begin{array}{c}\text { Urea } \\
(\mathrm{mg} / \mathrm{dL})\end{array}$ & $\begin{array}{c}\text { Creatinine } \\
(\mathrm{mg} / \mathrm{dL})\end{array}$ \\
\hline Control & $\begin{array}{l}15.5 \\
(0.6)\end{array}$ & $\begin{array}{l}76.8 \\
(0.9)\end{array}$ & $\begin{array}{r}101.4 \\
(0.7)\end{array}$ & $\begin{array}{l}65.2 \\
(0.9)\end{array}$ & $\begin{array}{l}47.3 \\
(0.3)\end{array}$ & $\begin{array}{r}103.7 \\
(1.5)\end{array}$ & $\begin{array}{r}116.5 \\
(1.4)\end{array}$ & $\begin{array}{l}47.7 \\
(0.5)\end{array}$ & $\begin{array}{r}1.3 \\
(1.5)\end{array}$ \\
\hline Diabetic control & $\begin{array}{r}5.1 \\
(0.3)\end{array}$ & $\begin{array}{r}160.7 \\
(1.3)\end{array}$ & $\begin{array}{r}189.7 \\
(1.4)\end{array}$ & $\begin{array}{l}30.5 \\
(0.5)\end{array}$ & $\begin{array}{r}115.3 \\
(1.2)\end{array}$ & $\begin{array}{r}206.7 \\
(1.7)\end{array}$ & $\begin{array}{r}178.8 \\
(1.8)\end{array}$ & $\begin{array}{l}68.7 \\
(1.3)\end{array}$ & $\begin{array}{r}1.7 \\
(1.0)\end{array}$ \\
\hline $\begin{array}{l}\text { Diabetic + Ethanolic } \\
\text { extract }(100 \mathrm{mg} / \mathrm{kg})\end{array}$ & $\begin{array}{l}12.8 \\
(0.4)\end{array}$ & $\begin{array}{r}134.6 \\
(0.9)\end{array}$ & $\begin{array}{r}147.7 \\
(1.2)\end{array}$ & $\begin{array}{l}39.3 \\
(1.2)\end{array}$ & $\begin{array}{l}57.5 \\
(0.5)\end{array}$ & $\begin{array}{r}183.5 \\
(1.0)\end{array}$ & $\begin{array}{r}155.9 \\
(1.0)\end{array}$ & $\begin{array}{l}55.4 \\
(0.5)\end{array}$ & $\begin{array}{r}1.7 \\
(0.5)\end{array}$ \\
\hline $\begin{array}{l}\text { Diabetic + Ethanolic } \\
\text { extract }(200 \mathrm{mg} / \mathrm{kg})\end{array}$ & $\begin{array}{l}13.8 \\
(0.7)\end{array}$ & $\begin{array}{r}119.8 \\
(1.1)\end{array}$ & $\begin{array}{r}124.6 \\
(1.2)\end{array}$ & $\begin{array}{l}48.8 \\
(1.0)\end{array}$ & $\begin{array}{l}31.4 \\
(1.2)\end{array}$ & $\begin{array}{r}175.2 \\
(1.5)\end{array}$ & $\begin{array}{r}134.5 \\
(1.3)\end{array}$ & $\begin{array}{l}48.5 \\
(1.5)\end{array}$ & $\begin{array}{r}1.5 \\
(0.9)\end{array}$ \\
\hline $\begin{array}{l}\text { Diabetic + } \\
\text { Glibenclamide (4 } \\
\mathrm{mg} / \mathrm{kg})\end{array}$ & $\begin{array}{r}14.4 \\
(0.7)\end{array}$ & $\begin{array}{r}122.8 \\
(1.0)\end{array}$ & $\begin{array}{r}150.3 \\
(0.8)\end{array}$ & $\begin{array}{l}59.9 \\
(0.7)\end{array}$ & $\begin{array}{l}49.3 \\
(0.5)\end{array}$ & $\begin{array}{r}162.4 \\
(1.0)\end{array}$ & $\begin{array}{r}122.7 \\
(0.8)\end{array}$ & $\begin{array}{l}49.9 \\
(1.8)\end{array}$ & $\begin{array}{r}1.4 \\
(0.9)\end{array}$ \\
\hline
\end{tabular}

All values are expressed as mean \pm SEM $(n=6)$

triglyceride and LDL level in diabetic induced rats while there was a significant reduction $(p<0.01)$ in HDL level. The ethanolic extract of P. hababianum of different concentration showed significant decrease $(p<0.01)$ in total cholesterol, triglyceride and LDL level and increased HDL level. Similarly there was a gradual increase $(p<0.01)$ in insulin level compared to the diabetic control group. Moreover, the reduction $(p<0.01)$ in SGPT, SGOT, urea and creatinine level were noted in diabetic treated rats which was shown in Table III.

\section{Discussion}

In current study, we have investigated the anti-oxidant and antidiabetic potential of $P$. hababianum. The scavenging of free radicals produced in our body is performed by the action of anti-oxidant molecules (Oboh et al., 2007). The ethanolic extract revealed the best activity of DPPH free radicals. The phenolic compounds existent in the plant extract can be responsible for the free radical scavenging activity, since it readily contributes hydrogen atoms to the free radical (Tung et al., 2009). The reducing capacity of plant extract was based on the capability to reduce $\mathrm{Fe}^{3+}$ to $\mathrm{Fe}^{2+}$. The different concentration of plant extracts posses various capacity of reduction ability as well as electron donating anti-oxidants (Halvorsen et al., 2002).

Ethanolic extracts of P. hababianum was investigated for the decreased blood glucose level in the streptozotocin induced diabetic rats as compared to the diabetic control and glibenclamide treated diabetic rats. The induction of diabetes using streptozotocin leads to
DNA strand breakage in $\beta$-cells of pancreas (Ponnusamy and Thangaraj, 2015). The occurrence of anti- diabetic activity is due to phenols, flavonoids, tannins and several other phytochemical compounds.

During the metabolic process, insulin activates lipoprotein lipase that hydrolyse the triglycerides (TG), deficiency or inactivation of these enzyme leads to hypertriglyceridemia (Maruthapandian and Mohan, 2011). Moreover, increase in fat diet leads to over helming of TG (Xu et al., 2005) and LDL level (Kesavalu et al., 2001) which leads to the artery hardening. Our investigation showed that was an increased HDL level that will ultimately reduce the complication of diabetes.

The reduction in the increased level of SGPT and SGOT in diabetic groups revealed that our extract may reduce the risk from liver failure linked with diabetes. Additionally, reduction in the urea and creatinine level may regress the metabolic homeostasis by crucially elicit the kidney function (Liaqat et al., 2014). The antidiabetic activity of ethanolic extract of P. hababianum possibly may due to potent anti-oxidant activity and thus it can be effective in preventing the oxidative and cellular damage of $\beta$-cells of pancreas.

\section{Conclusion}

Extracts of P. hababianum showed potential anti-oxidant activity against the free radical damage. The significant activity of these anti-oxidant leads to potent antihyperglycemic activity of ethanolic extract of $P$. hababianum by reducing the blood glucose level thus protecting our body from liver and kidney damage. 


\section{Ethical Issue}

The experimental study was approved by the committee for the purpose of control and supervision on experimental animals (CPCSEA) at animal house facility, K. S. Rangasamy College of Technology (1826/PO/EReBi/S/15/CPCSEA). The experiments were approved and done as per institutional animal ethics committee.

\section{Conflict of Interest}

All authors have completed the ICMJE uniform disclosure form and declare no support from any organization for the submitted work.

\section{References}

Atalay F, Halici MB, Mavi A, Cakir A, Odabasoglu F, Kazaz C, Aslan A, Kufrevioglu OI. Anti-oxidant phenolics from Lobaria pulmonaria (L.) Hoffm and Usnea longissima Ach. Lichen species. Turk J Chem. 2011; 35: 647-61.

Brown JE, Rice-Evans CA. Luteolin-Rich artichoke extract protects low density lipoprotein from oxidation in vitro. Free Radic Res. 1998; 29: 247-55.

Halvorsen BL, Holte K, Myhrstad MCW, Barikmo I, Hvattum E, Remberg SF. Systematic screening of total anti-oxidants in dietary plants. J Nutr. 2002; 132: 461-71.

Jeya PS, Selvambigai K, Ayyappadasan G, Ponmurugan P, Sanjeeva N. In vitro assessment of anti-oxidant and antimicrobial activities of different solvent extracts from lichen Ramalina neroulosa. Int J pharm and Pharm Sci. 2015; 7: 200-04.

Kesavalu M, Kemeshwara M, Rao B, Giri R. Lipid peroxidation and anti-oxidant enzyme status in type II diabetics with coronary heart disease. Diabetes Res Clin Pract. 2001; 53: 3339.

Khalaf NA, Shakya AK, Al-Othman A, El-Agbar Z, Farah H. Anti-oxidant activity of some common plants. Turk J Biol. 2008; 32: 51-55.

Ku G, Kegels G. The performance of the Finnish diabetes risk score: A modified Finnish diabetes risk score and a simplified Finnish diabetes risk score in community-based cross-sectional screening of undiagnosed type 2 diabetes in the Philippines. Prim Care Diabetes. 2013; 7: 249-59.

Liaqat H, Muhammad IQ, Shafiq-ur-Rehman. Antihyper- glycemic and hypolipidemic potential of Caesalpinia decapetala in alloxan-induced diabetic rabbits. Bangladesh J Pharmacol. 2014; 9: 529-32.

Maruthapandian A, Mohan VR. Antidiabetic, antihyperlipidaemic and anti-oxidant activity of Pterocarpus marsupium Roxb in alloxan-induced diabetic rats. Int J Pharm Tech Res. 2011; 3: 1681-87.

Muller K. Pharmaceutically relevant metabolites from lichens. Appl Microbiol and Biotech. 2001; 56: 9-16.

Oboh G, Puntel RL, Rocha JBT. Hot pepper (Capsicum annuum, Tepin and Capsicum Chinese, Habanero) prevents $\mathrm{Fe}^{2+}$ induced lipid peroxidation in brain in vitro. Food Chem. 2007; 102: 178-85.

Oyaizu M. Studies on product of browning reaction prepared from glucose amine. Jpn J Nutr. 1986; 44: 307-15.

Ponnusamy R, Thangaraj P. Antidiabetic analysis and insulin expression study of a wild leafy vegetable Acalypha alnifolia Klein ex wild. on streptozotocin-induced diabetic rats. Bangladesh J Pharmacol. 2015; 10: 461-66.

Ruch RJ, Cheng, Klaunig JE. Prevention of cytotoxicity and inhibition of intercellular communication by anti-oxidant catechins isolated from Chinese green tea. Carcinogenesis 1989; 10: 1003-08.

Sangameswaran B, Balakrishnan BR, Chumbhale D, Jayakar B. In vitro anti-oxidant activity of roots of Thespesia lampas. Pakistan J Pharm Sci. 2009; 22: 368-72.

Shih PW, Lai PL, William JH. Anti-oxidant activities of aqueous extracts of selected plants. Food Chem. 2006; 99: 775 -83 .

Slinkard K, Slingleton VL. Total phenolic analyses: Automation and comparison with manual method. Am J Enol Vitic. 1997; 28: 49-55.

Soxhlet F. Die gewichtsanalytische Bestimmung des Milchfettes. Polytech J (Dingler's). 1879; 232: 461-65.

Tung YT, Wu JH, Huang CY, Ku YH, Chang ST. Anti-oxidant activities and phytochemical characteristics of extracts from Acacia confusa bark. Bioresour Technol. 2009; 100: 509-14.

Walker FJ, James PW. A revised guide to microchemical technique for the identification of lichen products. Bull Bri Lic Soc. 1980; 46: 13-29.

$\mathrm{Xu} \mathrm{Y,} \mathrm{He} \mathrm{Z,} \mathrm{King} \mathrm{GL.} \mathrm{Introduction} \mathrm{of} \mathrm{hyperglycemia} \mathrm{and}$ dyslipidemia in the pathogenesis of diabetic vascular complications. Curr Diab Rep. 2005; 5: 91-97.

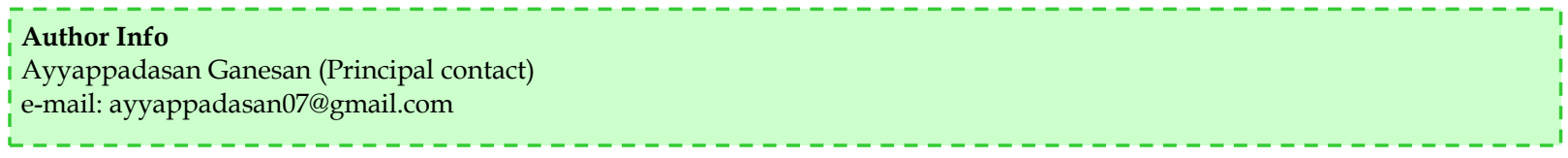




\section{Your feedback about this paper}

1. Number of times you have read this paper

2. Number of times you have seen the video clip

3. Quality of paper

4. Your comments 